\title{
PRÁTICAS DE LETRAMENTO NA INICIAÇÃO CIENTÍFICA E TECNOLÓGICA: UM ESTUDO DO GÊNERO RESUMO ACADÊMICO NO CEFET/RJ
}

\author{
LITERACY PRACTICES IN SCIENTIFIC AND TECHNOLOGICAL \\ INITIATION: A STUDY OF THE ACADEMIC ABSTRACT GENRE AT \\ CEFET/RJ
}

Maria Cristina Giorgi'

Fabio Sampaio de Almeida²

\begin{abstract}
Resumo: Temos como objetivo neste texto refletir acerca de relaçōes entre a iniciaçăo científica e tecnológica e o letramento profissional acadêmico de discentes participantes de projetos no Centro Federal de Educaçāo Tecnológica Celso Suckow da Fonseca - CEFET/RJ. Para tal, baseamos nossas discussōes em análises de resumos produzidos por sete orientandos de dois professores de unidades distintas da instituiçăo, relativos a trabalhos apresentados em eventos científicos diversos. Como aporte teórico, lançamos máo do conceito de gênero discursivo de Bakhtin (2000), bem como fazemos uma opçâo por um viés epistemológico que compreende os letramentos como práticas sociais situadas sócio-historicamente (BARTON, HAMILTON, 1998; DAVIES, MERCHANT, 2009; LANKSHEAR, KNOBEL, 2007). Nossos resultados apontam a relevância da iniciaçâo científica e, mais especificamente da produçâo de textos como o resumo acadêmico, para o letramento dos discentes e sua inserçăo em uma comunidade de pesquisadores.
\end{abstract}

Palavras-chave: Resumo acadêmico. Letramento profissional acadêmico. Iniciação científica. Gênero de discurso; CEFET/RJ.

Abstract: In this work, we investigate the links between technological and scientific initiation programs and the academic professional literacy of students engaged in projects at the Federal Center of Technological Education Celso Suckow da Fonseca -"

1 Centro Federal de Educaçâo Tecnológica Celso Suckow da Fonseca, CEFET/RJ. Docente do Programa de Pós-graduaçáo em Relaçôes Étnico-raciais, CEFET/RJ. Doutora em Estudos da Linguagem pela Universidade Federal Fluminense (2012). É líder de pesquisa do Grupo Práticas discursivas na produçăo de identidades sociais: Fatores humanos, organizaçōes, trabalho, tecnologia e sociedade (Cefet/RJ) e integra os grupos Práticas de Linguagem e discursividade (PraLinS-UERJ) e Práticas de linguagem, trabalho e formaçăo docente (UFF).E-mail: cristinagiorgi@terra.com.br.

2 Centro Federal de Educaçăo Tecnológica Celso Suckow da Fonseca, CEFET/RJ. Docente do Programa de Pós-graduaçāo em Relaçôes Étnico-raciais, CEFET/RJ. Doutor em Linguística Aplicada pela Universidade Federal do Rio de Janeiro (2014).E-mail: fabioesp@hotmail.com. 
Keywords: Academic abstract. Academic professional literacy. Scientific initiation. Discursive genre. CEFET/RJ.

\section{PRIMEIRAS CONSIDERAÇÕES}

Neste artigo nos propomos a produzir algumas reflexóes que perpassam o percurso de trabalho dos autores e seus respectivos orientandos - no programa de iniciaçáo científica (PIBIC) e iniciaçăo científica no Ensino Médio (PIBIC-EM), antes denominada iniciaçâo tecnológica ${ }^{3}$ (PIBIT) do CEFET/RJ - e pensar contribuiçōes, no que tange ao letramento profissional acadêmico, que os referidos programas podem trazer aos alunos que deles participam. Ou seja, tomamos a própria atividade de iniciaçăo científica como prática de letramento acadêmico.

A iniciaçâo científica neste âmbito é entendida como conjunto de atividades que fomenta o letramento profissional acadêmico, de modo a possibilitar a inserçáo no mundo da pesquisa acadêmica e a participaçấo em uma comunidade discursiva de investigadores, por meio da leitura e produçăo de textos acadêmico-científicos.

Dentro desse contexto, entendemos ser possível uma discussăo acerca do letramento acadêmico do discente a partir de uma análise de textos escritos por esses alunos que leve em conta uma visăo sócio-histórica e dialógica de/da língua(gem) e o conceito de gêneros do discurso de Bakhtin (2000), como caminho analítico que permita reflexôes sobre o papel da iniciaçăo científica na inserçâo desses estudantes no universo da pesquisa acadêmica. Nesse sentido, definimos como objetivo deste artigo analisar resumos acadêmicos produzidos por alunos de ensino médio e graduaçáo de modo a identificar marcas linguístico-discursivas que demonstrem o seu letramento acadêmico na iniciaçāo científica.

Com esse objetivo, selecionamos sete resumos acadêmicos produzidos por sete bolsistas de iniciaçâo científica, sendo três de graduaçăo e quatro de ensino médio, participantes de nossos projetos de pesquisa entre os anos de 2007 e 2012, entendendo essa produçáo como tipo específico de retextualizaçăo que deve considerar năo somente as condiçôes de produçấo, recepçăo e circulaçăo do resumo em si, como também aquelas do texto principal com o qual estes sempre dialogam - artigos, apresentaçóes orais etc. A escolha de tais produçōes deu-se em funçâo dos seguintes critérios: a) foi escolhido um resumo por aluno participante de projeto no recorte temporal estabelecido; b) foram selecionados aqueles textos que melhor caracterizam o gênero resumo acadêmico-científico

Fazemos aqui um parêntese para explicitar que na epistemologia sócio-histórica assumida neste texto, entendemos que năo há possibilidade de neutralidade na pesquisa e o pesquisador é um sujeito implicado. Desse modo, adotamos como caminho de pesquisa uma orientaçâo de viés autoetnográfico, metodologia que busca construir

3 Modalidade de Iniciaçâo científica voltada aos alunos do Ensino Médio e Técnico da instituiçāo. Atualmente passou a ser nomeada como Iniciação Científica - Ensino Médio (PIBIC-EM). Guardadas as devidas diferenças, especialmente no que diz respeito ao nível de ensino, doravante, entăo, optamos por utilizar a designaçáo iniciaçáo científica, neste artigo, para nomear ambos os programas, uma vez que todos os alunos participam conjuntamente de atividades de pesquisa desenvolvidas na articulaçáo com grupos de pesquisa consolidados na pós-graduaçâo. 
uma teorizaçăo e análise da própria experiência de práticas das quais pesquisador também assume a posiçâo de sujeito. Segundo Méndez (2013, p. 280), “a autoetnografia permite aos pesquisadores aproveitar suas próprias experiências para compreender um fenômeno ou cultura particular".

Pensando nas formas constituídas de conhecimento e nas relaçōes sócio institucionais, que se estabelecem dentro de um centro tecnológico, faz-se relevante, neste artigo, especialmente pelo viés autoetnográfico que norteia a pesquisa, explicitar nâo só o lugar do qual falamos, mas as implicaçōes que daí decorrem. Atuamos como professores de Língua Portuguesa e Língua Espanhola em instituiçăo na qual convivem, além dos ensinos Médio e Técnico, o Ensino Superior, de graduaçâo e pós-graduaçấo, lato e stricto sensu. Além disso, desde sua origem, o atual CEFET/RJ se relaciona com o ensino profissional e há muito tem sua realidade vinculada a disciplinas voltadas para o mundo das engenharias e afins, afirmaçăo que buscamos comprovar por meio da citaçâo retirada da página da instituiçâo, segundo a qual

O Centro é desafiado e se desafia, permanentemente, a contribuir no desenvolvimento do Estado do Rio de Janeiro e da regiăo. Atento às Diretrizes de Política Industrial, Tecnológica e de Comércio Exterior do país, voltase a uma formaçăo profissional que deve ir ao encontro da inovaçăo e do desenvolvimento tecnológico, da modernizaçăo industrial e potencializaçấo da capacidade e escala produtiva das empresas aqui instaladas, da inserçâo externa e das opçóes estratégicas de investimento em atividades portadoras de futuro - sem perder de vista a dimensăo social do desenvolvimento. Assim se reafirma como uma instituiçăo pública que deseja continuar a formar quadros para os setores de metalmecânica, petroquímica, energia elétrica, eletrônica, telecomunicaçôes, informática e outros que conformam a produçăo de bens e serviços no país (Disponível em: http://webhost01.cefet-rj.br/portal/ a-instituicao/historico.html).

Identifica-se, pois, a nosso ver, uma instituiçăo que faz claramente uma opçâo pelo mundo da tecnologia, da indústria, da produçăo. Mundo no qual o ensino de língua espanhola, nossa principal área de atuaçấo, năo é prioridade e em que cursos voltados para as humanidades, como o de turismo, representam ainda uma "minoria".

Após essa breve introduçâo, apresentamos as propostas teóricas com as quais dialogamos neste artigo, em seguida, as reflexôes feitas com base nas análises dos resumos, e, por fim, nossas consideraçóes finais.

\section{DO LETRAMENTO AO GÊNERO, NOSSAS OPÇÕES TEÓRICAS}

Para participar ativamente na vida de uma sociedade moderna, é preciso ler e escrever em diferentes gêneros discursivos, pois o letramento tornou-se essencial nas condiçôes públicas e privadas. Escrita e comunicaçăo sâo fatores de poder e de luta por hegemonia nos diferentes campos político-econômicos.

4 Tal afirmaçấo pode ser confirmada pela saída da grade da referida língua estrangeira de praticamente todos os novos cursos técnicos integrados da escola, permanecendo somente no curso de Turismo. 
Letramento na contemporaneidade é um conceito em expansăo, que vem se configurando como um construto múltiplo, deixando de se restringir ao âmbito escolar do aprendizado da leitura e da escrita. Passou, portanto, a constituir um campo de pesquisas que problematizam as relaçôes entre a produçấo e a circulaçăo de textos, em ambientes online ou offline, e outras dimensôes da vida social, tais como a construçáo de identidades profissionais, de classe social, de gênero e sexualidade etc. (BARTON, HAMILTON, 1998; DAVIES, MERCHANT, 2009; MOITA LOPES, FABRICIO, 2010).

Desse modo, é necessário explicitar que o entendimento que aqui fazemos do conceito afasta-se de qualquer perspectiva internalista ou meramente cognitivista, pois acreditamos que os letramentos - já que săo múltiplos - năo residem apenas na cabeça das pessoas como um conjunto de habilidades a serem aprendidas, e tampouco se localizam apenas nos textos, entendidos como portadores de um sentido único e estável; tomamos os letramentos como práticas sociais situadas sócio historicamente, de produçăo e circulaçăo de diferentes textos (orais, escritos e multimodais) e de sujeitos.

Barton e Hamilton (1998) destacam seu caráter de prática, definindo-o como alguma coisa que as pessoas fazem, ou seja, uma atividade, localizada na interseçăo entre o pensamento e o texto. E seu caráter social, "como toda atividade humana, 0 letramento é essencialmente social, e está localizado na interaçăo entre pessoas" (BARTON; HAMILTON, 1998, p. 3). Assim, o letramento como prática social focaliza o modo como diferentes sujeitos ao produzir e ler textos constroem sentidos através da interaçâo contextualizada (DAVIES; MERCHANT, 2009).

De acordo com Lankshear e Knobel (2007, p. 64), os letramentos săo "modos socialmente reconhecidos de geraçăo, comunicaçaao e negociaçaáo de conteúdos significativos por meio de textos codificados em contextos de participaçâo em discursos", isto é, como membros de comunidades que produzem e sustentam determinados discursos. Sendo assim, no caso da iniciaçăo científica, entendida como espaço de letramento acadêmico profissional, os alunos negociam significados sobre as pesquisas que desenvolvem e sobre quem săo como pesquisadores em formaçăo, ao produzir textos codificados em determinados gêneros, como o resumo acadêmico.

Essa definiçáo busca reunir e explicitar a compreensáo de letramentos que sustentam os autores. Para eles, os letramentos envolvem:

a) um conjunto de práticas socialmente organizadas, sendo prática aqui entendida no sentido da açăo, de maneiras socialmente desenvolvidas e padronizados de usar a tecnologia e o conhecimento para realizar tarefas;

b) a produçăo de conteúdos significativos, gerados nas trocas interacionais com outros textos e com os destinatários que sấo convidados a fazer sentido de nossos textos;

c) a geraçấo e circulaçâo de textos codificados, "congelados" ou "capturados", que săo transportáveis de um espaço a outro e que ganham existência para além de seus autores;

d) a atualizaçáo de sujeitos situados que fazem suas vidas nas trocas e no 
pertencimento a grupos sociais e culturais, simultaneamente produtores e produzidos por discursos com os quais se identificam.

Faz-se relevante acrescentar que, no intuito de compreender as implicaçóes do letramento, é preciso abandonar a ideia de uma competência leitora universal e única, sem, contudo ignorar as relaçôes subjacentes e os temas comuns nas diferentes práticas de letramento, uma vez que, ainda que se discuta e se proponha o trabalho com diferentes gêneros discursivos na escola, a crença em uma habilidade leitora universal/ geral parece ainda direcionar as políticas de escolarizaçăo no país.

Definido nosso entendimento sobre letramento, nos detemos a partir de agora no conceito de gêneros do discurso, mais especificamente nas propostas de Bakhtin (2000), fundamental para nossas reflexóes.

Ainda que saibamos que é possível relacionar o conceito de gênero à filosofia clássica de Aristóteles, ao Romantismo dos séculos XVIII e XIX e aos formalistas russos do início do século passado, nos pautamos nas reflexôes de Bakhtin para quem o interesse pelos gêneros náo se restringiu aos estudos literários, seu foco inicial. Ao contrário de perspectivas estruturalistas, visâo ainda vigente nos estudos gramaticais e no ensino de línguas em nosso contexto, que privilegiavam os aspectos formais e estruturais da língua, Bakhtin a compreende como atividade social e histórica e nos apresenta os gêneros do discurso como tipos relativamente estáveis de enunciados utilizados em uma determinada situaçâo de enunciaçâo como formas marcadas a partir de contextos sociais e históricos, sujeitas a alteraçōes em sua construçăo composicional, de acordo com seu contexto de produçáo e dos falantes/ouvintes.

Pode-se entender, pelas propostas de Bakhtin (2000), que nosso modo de ver e experienciar a realidade humana é moldado pelos gêneros do discurso. Sendo assim, aprender novos gêneros, logicamente, é aprender a ver de modo diferente e a expandir o repertório de visâo para a realidade social que nos cerca (BAKHTIN, 1928 apud ACOSTA-PEREIRA, 2013). Ou

Como pontua Faraco (2009), novos meios de expressăo e representaçăo do real forçam-nos a visualizar e a compreender novos aspectos da realidade visível. Para o autor, o que Bakhtin; Medviédev (2012[1928]) explicam é que vemos a realidade com os olhos do gênero. Assim, diferentes gêneros veem o mundo de maneiras diferentes e incompatíveis e, por conseguinte, cada gênero passa, entâo, a ser adaptado para conceitualizar alguns aspectos da realidade melhor do que outros. Segundo Bakhtin (2008[1929]), as pessoas e as culturas precisam apreender e aprender historicamente novos gêneros, à medida que se expande o âmbito de suas experiências. Cada gênero possui princípios definidos de seleçấo de aspectos do real e, com isso, se mostra inadequado para conceitualizar realidades de outros gêneros (ACOSTA-PEREIRA, 2013, p. 497)

É também o gênero que garante a comunicaçăo aos falantes de uma língua, pois permite uma economia cognitiva (MAINGUENEAU, 2002) entre os interlocutores, pois como coloca Bakhtin (2000, p. 302), "Se năo existissem os gêneros do discurso e se năo os dominássemos, se tivéssemos de criá-los pela primeira vez no processo da fala, se tivéssemos de construir cada um de nossos enunciados, a comunicaçáo verbal seria quase impossível". Apenas conhecer bem uma língua e ser capaz de dominá-la em determinados contextos náo garante ao falante comunicar-se em todas as esferas. 0 
reconhecimento de características particulares que distinguem um gênero de outro permite ao interlocutor estabelecer as bases do seu entendimento, uma vez que uma fala inscrita em determinado gênero fornece pistas por meio das quais este possa se situar dentro do contexto da comunicaçăo, prevendo suas características e finalidades. Ou seja, dentro de uma dada situaçăo linguística, os interlocutores produzem uma estrutura comunicativa que se configurará nesses tipos relativamente estáveis de enunciado, situados a partir de contextos sociais e históricos. Essas formas estâo sujeitas a alteraçōes em sua estrutura, e refletem as condiçóes específicas e as finalidades de cada esfera social, que nada mais sâo do que princípios organizadores dos gêneros.

Seguindo as propostas de Bakhtin, todo gênero reflete as condiçōes específicas e as finalidades de cada esfera social por meio da relativa regularidade de: conteúdo temático, estrutura composicional e estilo, divisăo fundamental no escopo deste artigo.

O conteúdo temático se relaciona com o modo de o gênero selecionar elementos da realidade e de tratá-los na constituiçăo de seu domínio de sentido. Abarca o sentido ideológico global do enunciado e se diferencia de acordo com as situaçôes de interaçâo. Cabe lembrar que diferente de ser o assunto, esse se relaciona ao domínio de sentido de que esse gênero se ocupa. A estrutura composicional relaciona-se à organizaçăo, considerando tipos de construçâo do conjunto, todos de acabamento e de relaçấo entre os parceiros da comunicaçấo. Por sua vez, o estilo se vincula à interlocuçâo EU-VOCÊ, às escolhas feitas pelo enunciador no diálogo com o seu coenunciador dentro da gama de recursos linguísticos que é oferecida dentro de cada gênero. Assim, o diferencial na proposta bakhtiniana de estilo é sua relaçăo constitutiva com a noçăo de gênero do discurso

Em diálogo com Bakhtin, Rampton (2006) destaca que o "estilo", tradicionalmente, é compreendido, como um modo "natural" de usar a linguagem, característico de determinados sujeitos ou de identidades sociais e culturais essencializadas. Opondo-se a uma estilística tradicional da língua, Bakhtin (2000) discute em seus trabalhos uma concepçăo de estilo que se afasta do modelo essencializado de língua que se funda em uma "expressăo individual" produzida por uma suposta subjetividade pessoal e privada. A concepçăo bakhtiniana de estilo está orientada pela e para a enunciaçăo, na relaçâo do locutor com o outro, interlocutor, e com outros discursos.

Para Bakhtin, o estilo é uma dimensâo enunciativa característica do discurso em seu funcionamento dialógico. Desse modo, o estilo faz uso das formas da língua em usos situados e concretos, é definido pelas escolhas que faz o participante, levando sempre em consideraçăo o gênero de discurso mobilizado e os interlocutores.

Como componente do gênero, o estilo está indissociavelmente ligado a unidades temáticas e a unidades composicionais. Aos diferentes gêneros produzidos nas mais diversas esferas de atividade humana correspondem estilos determinados, alguns mais padronizados, como no caso de documentos oficiais e cerimônias com protocolos rígidos, e outros mais autorais, como é o caso dos gêneros literários e publicitários. Assim, o estilo aponta para a negociaçâo entre uma dimensâo coletiva, típica do gênero, produzida sócio-historicamente e acumulada na forma de modelos e uma dimensăo emergente e contingente, situada no aqui e agora dos participantes em açăo. O estilo depende da relaçấo que se produz entre o locutor, os demais parceiros da interaçáo (sejam reais ou imaginados) e os outros discursos. Desse modo, ao escrever resumos 
acadêmicos, enuncia-se em um estilo ligado à esfera da produçăo científica específica, nesse caso da pesquisa em linguística aplicada em um centro federal tecnológico.

Desse modo, entendemos ser possível articular a noçăo de gêneros do discurso à de letramentos, tendo em vista que as práticas de letramento se dâo a partir de diferentes gêneros, pertencentes à diferentes esferas de atividade humana. O gênero também constitui àquilo a que Lankshear e Knobel (2007) chamam de textos codificados. Passamos a seguir às análises dos resumos selecionados.

\section{CONTRIBUIÇÕES A PARTIR DA ANÁLISE DOS RESUMOS ACADÊMICOS}

Antes de iniciarmos nossas análises, faz-se necessário esclarecer que, apesar das diferenças que os distintos contextos de produçâo e circulaçăo relativos aos resumos acarretam à mobilizaçăo do gênero, especificamente no que diz respeito ao lugar de enunciaçâo de alunos dos níveis médio e superior, focalizamos neste artigo a dimensâo de relativa estabilidade à que Bakhtin (2000) se refere ao definir o conceito, o que nos possibilita de modo mais amplo analisar o processo de letramento dos alunos envolvidos. Dito isso, passamos às nossas consideraçóes, retomando a já citada proposta do filósofo russo que consideram o gênero desde condiçóes específicas e finalidades de cada esfera social por meio da relativa regularidade de conteúdo temático, estilo e estrutura composicional. Năo podemos deixar de considerar, contudo, que, conforme o próprio filósofo, esses elementos săo indissociáveis. Assim, a divisăo aqui encaminhada deve-se apenas à necessidade de organizaçăo de nossas análises.

Considerando as coerçōes a que está submetido o gênero, a estrutura composicional dos resumos em questáo analisados se organiza a partir da presença ou ausência de determinados movimentos retóricos que identificamos como:

- contextualizaçấo da pesquisa;

- exposiçăo do problema de pesquisa;

- construçăo de justificativas para a pesquisa;

- identificaçăo dos objetivos;

- formulaçăo de hipóteses;

- fundamentaçăo teórica ou teórico-metodológica;

- explicitaçấo de procedimentos metodológicos;

- relato das atividades desenvolvidas na pesquisa;

- apresentaçăo de conclusóes.

Apenas levando em conta os tópicos acima, já seria possível verificar que o processo de letramento acadêmico na produçăo de resumos dialoga com a anteriormente anunciada compreensâo de letramento como prática social (LANKSHEAR, KNOBEL, 2007), uma vez que os alunos produziram textos codificados e adequados às coerçôes do gênero resumo acadêmico. No entanto, interessa-nos dar visibilidade ao modo como tais elementos da estrutura composicional do gênero sâo produzidos a partir de um estilo e de uma abordagem temática que contribuem para a produçăo de subjetividade do pesquisador. 
Considerando os objetivos e limitaçôes deste texto, no que concerne à possibilidade de realizaçấo de análises de todos esses movimentos em nosso corpus, optamos por focalizar aqueles que, a nosso ver, melhor explicitam o processo de letramento tomado como prática social. Para efeito de análise, entăo, decidimos discorrer sobre dois movimentos retóricos: um presente na lista e que ora desenvolvemos - o relato de atividades desenvolvidas na pesquisa - e outro nấo, que será desenvolvido em um segundo momento.

Os textos dos resumos - mais especificamente no que tange ao relato de atividades desenvolvidas pelos alunos ao longo de suas trajetórias como participantes de projetos de iniciaçăo científica ou tecnológica - constroem discursivamente um posicionamento no processo de "tornar-se pesquisador"; isto é, atuam na produçáo de saberes e refletem a construçáo da subjetividade de pesquisador. 0 movimento de relatar as atividades desenvolvidas demonstra a compreensâo da produçăo do texto acadêmico no gênero resumo como um momento de dar visibilidade ao processo de pesquisa desenvolvido em diversas etapas. Desse modo, é possível asseverar que tal movimento também constitui uma forma, construída por meio de um letramento, de construir participaçăo em uma comunidade acadêmica, alinhando os pesquisadores a uma tendência contemporânea de produçâo de conhecimentos em ciências sociais e humanas que rompe com a epistemologia positivista de pesquisa. Os fragmentos nos quais identificamos tais características são:

Resumo 1: "Durante dois anos de pesquisa, apresentamos pôsteres e comunicaçáo coordenada em congressos e eventos no CEFET/RJ, na UERJ e na Faculdade de Formaçâo de Professores da UERJ. Fizemos reuniōes para leitura e discussăo de textos relacionados ao projeto, entre outras atividades [...]"

Resumo 2: "Com o decorrer do projeto pôsteres e apresentaçōes de slides, além de resumos e relatórios foram feitos para que pudéssemos divulgar năo só aqui, mas em outras instituiçôes os objetivos de nossa pesquisa [...]"

Resumo 4: "Após a percepçâo de que nossa área de pesquisa era muito extensa, decidimos recortar e pesquisar informaçōes apenas em um país, que ainda assim năo tivemos resultados. Tivemos a iniciativa de uma segunda etapa, que consistia na busca por contato com os professores da língua espanhola das Unidades do CEFET do Estado do Rio de Janeiro para ter conhecimento dos métodos de ensino e em seguida iríamos aplicar questionários aos professores para compreender a importância da aplicaçăo da disciplina em sala de aula."

Resumo 5: "Dessa forma, será possível coletarmos dados de toda a situaçăo de trabalho, do treinamento até a aplicaçăo real, estando junto aos agentes de viagens nas etapas necessárias para a realizaçăo do seu trabalho."

Nos fragmentos, destacam-se os dêiticos de pessoa, como elemento linguístico- discursivo que, além de construir na enunciaçáo sentidos de pertencimento para os enunciadores enquanto sujeitos atuantes nas respectivas pesquisas, fonte do que é dito, situa o letramento acadêmico ao apontar para a participaçấo em uma comunidade científica. E o uso da primeira pessoa do plural, do ponto de vista bakhtiniano, aponta, por um lado, para a expressividade dos locutores no gênero, e por outro, para uma construçấo coletiva de um modo de ver e fazer ciência na qual o pesquisador nấo 
é neutro ou está dissociado da pesquisa. Tais usos dos recursos léxico-gramaticais já constituem elementos que vem a caracterizar um estilo do gênero em questăo.

Esse segundo movimento retórico que se destaca nos remete a um trabalho de reflexâo que, na articulaçấo entre a reformulaçấo das hipóteses e a reflexăo sobre os resultados, atua na construçáo de sujeitos pesquisadores que participam de uma comunidade acadêmica, como podemos observar nos próximos fragmentos:

Resumo 1: "[...] percebemos que algumas hipóteses, inicialmente levantadas por nós, bolsistas, foram confirmadas e outras năo se confirmaram".

Resumo 2: "[...] percebemos que năo deveríamos afirmar que năo há espaço para estas dentro do CEFET/RJ, pois mesmo estando em minoria, sempre tivemos a oportunidade de desenvolver nossos trabalhos".

Resumo 3: “[...] fomos percebendo que a área de humanas conquistou um espaço dentro da instituiçăo, e que apesar de a minoria dos projetos serem ainda nas chamadas ciências exatas, nâo há dentro do CEFET/RJ obstáculos para a realizaçăo de projetos em outras áreas".

Também é perceptível nos três excertos acima a ocorrência de marcas que contrariam uma visăo que pretende uma pesquisa que conta uma verdade total e definitiva. Por exemplo, em "percebemos que năo deveríamos afirmar que năo há espaço para estas dentro do CEFET/RJ" o uso do condicional deveríamos precedido do advérbio de negaçăo năo, dialoga com uma proposta inicial para a qual năo haveria um espaço para as ciências humanas em instituiçăo voltada para a área de exatas, que năo se confirma. O mesmo diálogo que podemos identificar em "que apesar de a minoria dos projetos serem ainda nas chamadas ciências exatas, năo há dentro do CEFET/RJ obstáculos para a realizaçăo de projetos em outras áreas". Tal encaminhamento aponta para uma visâo de pesquisa que aceita o năo comprovar uma hipótese inicial e como afirma (COSTA, 2004a, p. 5) "abdicar à pretensâo de totalidade também significa admitir e aceitar a provisoriedade do conhecimento".

Problematizando os mesmos fragmentos citados, é possível perceber o papel do estilo no processo de letramento de seus autores. Bakhtin (2000) o considera a partir de duas perspectivas: a do estilo individual - resultado das escolhas do enunciador - e a das práticas de linguagem - fruto da convergência de usos linguísticos, textuais e discursivos recorrentes em um dado contexto enunciativo. $O$ estilo, desse modo, acontece desde a tensâo entre uma vontade individual e uma coerçáo dada a priori pelo gênero, que, no caso dos resumos analisados, se verifica pelo uso da forma verbal "percebemos". Se esta, por um lado, substitui uma primeira pessoa do singular, que marcaria de modo mais explícito as opinióes do enunciador, por outro, náo segue as rígidas normas do discurso acadêmico-científico de áreas nas quais a lógica é um total apagamento do sujeito. Entendemos, portanto que "percebemos", marca discursivamente a referida tensâo, tendo em vista a construçăo de uma concepçâo de pesquisa onde a subjetividade do pesquisador náo é negada, mas sim constitui um elemento central na produçâo de conhecimentos.

Concluímos nossas análises, retomando o que afirma Bakhtin (2000) acerca da dificuldade em desatrelar conteúdo temático, estilo e estrutura composicional, quando 
tratamos de gênero. Os três componentes, nâo devem, portanto, ser entendidos de maneira estanque. Ou, conforme Bakhtin, "o estilo é indissociável de determinadas unidades temáticas e - o que é de especial importância - de determinadas unidades composicionais" (2000, p. 266).

Apresentamos, em seguida, com base nas reflexóes aqui expostas, nossas últimas consideraçōes.

\section{CONSIDERAÇÕES FINAIS}

Neste artigo, propusemos como objetivo refletir sobre contribuiçóes dos programas de iniciaçăo científica do CEFET/RJ no que se refere ao letramento profissional acadêmico de seus alunos, a partir da compreensăo de que a iniciaçăo científica pode ser entendida como prática de letramento acadêmico. Norteamos nossa discussáo nas análises de resumos produzidos por alunos de iniciaçăo científica participantes de nossos projetos de pesquisa.

O estudo dos resumos acadêmicos produzidos por esses discentes possibilitou analisar práticas de letramento acadêmico, nas quais o processo de tornar-se pesquisador constrói-se discursivamente; atuando na produçăo de saberes e refletindo a construçâo da subjetividade de pesquisador. Ao produzir textos, produzem-se sujeitos simultaneamente, sujeitos esses que passam a participar de uma comunidade acadêmica. Ou seja, a leitura e produçáo de textos acadêmico-científicos propicia a inserçăo no mundo da pesquisa acadêmica, e o gênero resumo acadêmico é o modo de iluminar o processo de pesquisa desenvolvido em diversas etapas e o marco de uma participaçăo na vida acadêmica, dentro de visáo de pesquisa contemporânea de produçăo de conhecimentos em ciências sociais e humanas que se afasta de uma epistemologia positivista de pesquisa.

Destacaram-se também recursos léxico-gramaticais que já constituem elementos que constroem sentidos de pertencimento na enunciaçăo para os enunciadores, ressaltado seu engajamento enquanto sujeitos atuantes nas pesquisas, parte de uma comunidade científica, bem como a opçăo por uma construçấo coletiva de um modo de ver e fazer ciência que náo separa o pesquisador da pesquisa como um ser neutro. 0 pesquisador năo é neutro ou está dissociado da pesquisa e acredita na provisoriedade do conhecimento.

Desse modo, entendemos que a produçâo do gênero resumo acadêmico reitera o entendimento de letramento como prática social que focaliza o modo como diferentes sujeitos ao produzir e ler textos constroem sentidos através da interaçăo contextualizada (DAVIES; MERCHANT, 2009), além de esses resumos constituírem "modos socialmente reconhecidos de geraçấo, comunicaçăo e negociaçăo de conteúdos significativos por meio de textos codificados em contextos de participaçăo em Discursos" (LANKSHEAR, KNOBEL, 2007, p. 64). 


\section{REFERÊNCIAS:}

ACOSTA-PEREIRA, R.. A prática de análise linguística mediada pelos gêneros do discurso: matizes sócio-históricos. In: Letrônica, Porto Alegre, v. 6, n. 2, p. 494-520, jul./dez., 2013 BAKHTIN, M. Estética da criaçâo verbal. Săo Paulo: Martins Fontes, 2000.

BARTON, D.; HAMILTON, M. Local literacies: reading and writing in one community. London: Routledge, 1998.

COSTA, M. (Org.) Caminhos Investigativos. Novos olhares na pesquisa em educaçăo. Porto Alegre: Mediaçāo, 2004.

COSTA, M. (Org.)O diálogo entre a ciência e o mundo - uma agenda para jovens pesquisadores e pesquisadoras. In: Caminhos Investigativos. Novos olhares na pesquisa em educaçăo. Porto Alegre: Mediaçăo, 2004a.

DAVIES, J.; MERCHANT, G. Web 2.0 for schools. Learning and social participation. New York: Peter Lang, 2009

FARACO, C. Linguagem e diálogo: as ideias do Círculo de Bakhtin. Săo Paulo: Parábola, 2009.

LANKSHEAR, C.; KNOBEL, M. New literacies. Everyday practices and classroom learning. Berkshire: MCGraw Hill- Open University, 2007

MAINGUENEAU, D. Análise de textos de comunicaçâo. Săo Paulo: Cortez, 2002.

MÉNDEZ, M. Autoethnography as a research method: Advantages, limitations and criticisms. Colombian Applied Linguistics Journal, 15(2), p. 279-287, 2013.

MOITA LOPES, L. P. da; FABRICIO, B. F. A dinâmica dos (re)posicionamentos de sexualidade em práticas de letramento escolar. In: MOITA LOPES, L.P.; BASTOS, L. C.. (Org.). Para além da identidade. Fluxos, movimentos e trânsitos. Belo Horizonte: Editora UFMG, 2010.

Recebido em janeiro de 2017.

Aceite em fevereiro de 2018. 


\section{ANEXOS:}

\section{RESUMO 1}

\section{Ensino, pesquisa e extensáo: o espaço das Ciências Humanas}

Iniciamos nosso projeto a partir de algumas visōes e questionamentos que tínhamos a respeito do CEFET/RJ, no que tange ao espaço que diferentes áreas de ensino ocupam na mesmo. A oportunidade de conhecer melhor a instituiçáo e o universo da pesquisa nos levou a perceber que essa investigaçăo poderia ser de grande valia para nosso futuro acadêmico, e servir de motivaçăo para que a realizaçăo do referido projeto. Durante dois anos de pesquisa, apresentamos pôsteres e comunicaçáo coordenada em congressos e eventos no CEFET/RJ, na UERJ e na Faculdade de Formaçáo de Professores da UERJ. Fizemos reunióes para leitura e discussăo de textos relacionados ao projeto, entre outras atividades e percebemos que algumas hipóteses, inicialmente levantadas por nós, bolsistas, foram confirmadas e outras năo se confirmaram. O objetivo deste relatório é comparar resultados de pesquisas feitas sobre a instituiçăo e fazer um balanço sobre como nossos conceitos mudaram com o passar do tempo. Também apresentamos, resumidamente, as atividades desempenhadas por nós durante a execuçâo do projeto. O destaque do último semestre foi a leitura e discussăo de textos sobre a elaboraçăo de entrevistas e sua utilizaçáo em pesquisas acadêmicas. 


\section{RESUMO 2}

Ensino, pesquisa e extensăo: uma discussăo para o Ensino Médio?

Em meados de 2007 este projeto se iniciou buscando divulgar as pesquisas de Iniciaçâo Tecnológica dentro do CEFET/RJ, que já existiam, mas, em nossa opiniâo nâo eram muito populares entre uma grande parte de docentes e discentes. Para que isso fosse possível nosso grupo de pesquisa - que integra o projeto 'Ensino, pesquisa e extensâo: caminhos possíveis' - desenvolveu projetos individuais buscando fazer um mapeamento DOS projetos tecnológicos desenvolvidos nas diferentes áreas do CEFET. Num primeiro momento, nossos resultados apontaram para uma desvalorizaçăo das áreas chamadas Ciências Humanas, com relaçầo às Ciências Exatas, o que nos fez pensar em como isso tudo começou. Fizemos a hipótese de que essa desigualdade era histórica, devido à instituiçâo ser de caráter tecnológico, e que no seu início as matérias Humanas nem eram lecionadas. Com o decorrer do projeto pôsteres e apresentaçóes de slides, além de resumos e relatórios foram feitos para que pudéssemos divulgar năo só aqui, mas em outras instituiçóes os objetivos de nossa pesquisa, e a partir de melhor conhecer as pesquisas das outras áreas percebemos que năo deveríamos afirmar que nâo há espaço para estas dentro do CEFET/RJ, pois mesmo estando em minoria, sempre tivemos a oportunidade de desenvolver nossos trabalhos. como resultado parece-nos possível dizer que o Ensino Médio está preparado para começar pesquisas, projetos de extensấo e conciliar com os estudos, e nâo só os alunos dos técnicos e da graduaçấo, como sugerem os nomes das pesquisas. 


\section{RESUMO 3}

Cartografando a pesquisa dentro do CEFET/RJ: história e novas perspectivas

O início de nosso trabalho foi motivado por nossa vontade de dar maior visibilidade às pesquisas de Iniciaçăo Tecnológica realizadas no CEFET-RJ. Fazíamos algumas hipóteses: 1) de que era dado mais destaque à área tecnológica em relaçâo à área de humanas; 2) que havia uma pequena participaçâo do Ensino Médio na realizaçấo das mesmas e 3) de faltar um intercâmbio entre pesquisas realizadas no CEFET/RJ. Após levantamentos da história da instituiçấo, justificamos que o maior destaque dado à área de exatas se deve ao passado da instituiçăo, que possui um caráter tecnológico, voltado para a formaçáo para a indústria. Entretanto, através de discussóes, apresentaçóes de pôsteres em congressos, apresentaçóes em slides, relatórios e resumos fomos percebendo que a área de humanas conquistou um espaço dentro da instituiçăo, e que apesar de a minoria dos projetos serem ainda nas chamadas ciências exatas, năo há dentro do CEFET/RJ obstáculos para a realizaçăo de projetos em outras áreas. Confirmamos também, que poucas pesquisas săo realizadas no Ensino Médio e que a grande concessâo de bolsas é destinada ao ensino superior. Também, contrariando o que pensávamos, soubemos que docentes da área de exatas também desenvolvem temas da área de humanas em suas pesquisas, o que nos faz pensar que é necessário dar mais visibilidade aos projetos desenvolvidos, além de ser essencial uma melhor comunicaçâo entre as pesquisas dentro da instituiçâo. Pensamos, entâo que todas as áreas sâo relevantes para a instituiçăo sendo preciso que cada um lute pelo seu espaço. 


\section{RESUMO 4}

Relaçăo ensino, pesquisa e extensăo no EM.

Este trabalho tem o objetivo de dar visibilidade ao ensino da língua espanhola como uma importante disciplina e como ferramenta que contribui na formaçâo do aluno como cidadáo. O projeto passou por três etapas fundamentais para seu desenvolvimento e amadurecimento. Na primeira etapa entramos em contato com o Ministério da Educaçăo de três países selecionados para solicitar a listagem de escolas em nível médio presentes nestes, onde nâo obtivemos respostas. Após a percepçáo de que nossa área de pesquisa era muito extensa, decidimos recortar e pesquisar informaçóes apenas em um país, que ainda assim năo tivemos resultados. Tivemos a iniciativa de uma segunda etapa, que consistia na busca por contato com os professores da língua espanhola das Unidades do CEFET do Estado do Rio de Janeiro para ter conhecimento dos métodos de ensino e em seguida iríamos aplicar questionários aos professores para compreender a importância da aplicaçâo da disciplina em sala de aula. Nesta fase do trabalho, compreendemos que é essencial que a área de pesquisa explorada deve estar próxima ao local de trabalho para facilitar o contato. Assim, surgiu a terceira etapa, onde direcionamos nossa área de pesquisa para o curso Técnico em Turismo do CEFET/ RJ. Nesta etapa, buscamos compreender a importância da língua espanhola para o curso, o papel que ela exerce dentro de sala de aula e a opiniâo dos alunos em relaçáo à mesma. Para isso, foram aplicados questionários aos alunos do $5^{\circ}$ e $6^{\circ}$ períodos para obtermos resultados mais concretos e de alguma forma contribuir para o reconhecimento da disciplina dentro da Unidade do CEFET/RJ. 


\section{RESUMO 5}

Língua espanhola nas agências de viagens: um estudo discursivo

O objetivo do trabalho proposto é identificar os gêneros que săo freqüentes no uso da língua espanhola em atividades dos agentes de viagens em Petrópolis, e em que medida é relevante para esses profissionais possuírem essa língua em suas atividades nas agências de viagens. O referencial teórico se baseia em estudos que articulam uma perspectiva discursiva de linguagem (BAKHTIN, 2003) a uma visăo do trabalho (SCHWARTZ, 2000). O referencial é sustentado principalmente por uma ótica da Lingüística Aplicada. Faz-se necessário para a melhor compreensâo dos resultados que serâo apresentados, situar a pesquisa com conceitos de trabalho e linguagem para posteriormente avançarmos para o objetivo do projeto. Os sujeitos de pesquisa seráo profissionais do departamento de reservas, graduados ou năo em turismo, que atuam em uma agência de viagens e turismo em Petrópolis. A pesquisa tem cunho qualitativo e interpretativista. As ferramentas utilizadas para alcançar os objetivos propostos pelo trabalho serâo questionários aplicados aos agentes de viagens e observaçâo participante junto a esses profissionais em seus ambientes de trabalho. Dessa forma, será possível coletarmos dados de toda a situaçăo de trabalho, do treinamento até a aplicaçâo real, estando junto aos agentes de viagens nas etapas necessárias para a realizaçấo do seu trabalho. O projeto final tem previsăo de conclusăo para agosto de 2011. 


\section{RESUMO 6}

Linguagem e atividade de trabalho em turismo: um estudo discursivo

A presente comunicaçâo objetiva discutir a complexidade das relaçóes entre linguagem e trabalho na área de Turismo, nos campos de atuaçaáo profissional e formaçâo acadêmica, a partir da análise das práticas de linguagem em suas distinçôes e imbricaçōes (NOUROUDINE, 2002), além de problematizar a relevância do uso da língua estrangeira em atividades profissionais, em tempos de "globalizaçăo". Especificamente, propóe-se o estudo de discursos produzidos por alunos do Curso Superior de Tecnologia em Gestăo de Turismo do CEFET - UneD Petrópolis, investigando assim, crenças e expectativas evidenciadas em relaçấo à escolha do curso e seu desenvolvimento e ao papel da língua estrangeira para aqueles que almejam trabalhar ou já se encontram atuando em uma ou mais áreas relacionadas ao campo do Turismo. Como marco teórico-metodológico, considerando a contribuiçâo dos estudos da linguagem para a compreensâo de práticas sociais (DAHER, 2007), a pesquisa se orienta por um viés que articula a concepçâo dialógica da linguagem (BAKHTIN, 2000) aos estudos enunciativos de Dominique Maingueneau (1997; 2002). Os dados foram gerados através de uma abordagem enunciativa, com questionários aplicados aos alunos do terceiro período (primeira turma do curso), de enfoque qualitativo. A análise parcial dos dados se construiu através da observaçăo de marcas lingüísticas no discurso produzido pelos participantes. Entende-se que, ao produzir um discurso, o sujeito se posiciona como fonte de referências pessoais, temporais, espaciais e, ao mesmo tempo, sugere que atitude está tomando em relaçăo àquilo que é dito e em relaçăo a seu co-enunciador (MAINGUENEAU, 2002). Quanto aos resultados parciais, observou-se igualmente grande heterogeneidade no discurso dos participantes e em seus posicionamentos. 


\section{RESUMO 7}

Um estudo discursivo acerca do uso da língua estrangeira em atividades de trabalho em turismo

O objetivo desta pesquisa foi discutir crenças e expectativas de alunos do Curso Superior de Tecnologia em Gestăo de Turismo do CEFET/RJ- UnED Petrópolis, relacionadas à escolha do curso e seu desenvolvimento e ao papel atribuído à língua estrangeira em atividades profissionais de Turismo. Buscamos assim, problematizar a complexidade das relaçóes entre linguagem e trabalho, nos campos de atuaçăo profissional e formaçăo acadêmica, e a relevância do uso da língua estrangeira, em tempos de "globalizaçâo". Nosso quadro teórico se pauta numa perspectiva discursiva da linguagem voltada para a compreensăo de práticas sociais (DAHER, 2007), articulamos a concepçăo dialógica da linguagem (BAKHTIN, 2000) aos estudos enunciativos de Dominique Maingueneau (1997; 2002). A geraçâo de dados se deu através de uma abordagem enunciativa de enfoque qualitativo, com questionários aplicados aos alunos do terceiro período. Os resultados parciais apontam para heterogeneidade em relaçăo às respostas dos mesmos. Os alunos enfatizam a necessidade da língua estrangeira para as atividades profissionais do turismo, se pautando em crenças construídas no diálogo com discursos do mundo dos negócios que afirmam a importância da língua estrangeira como facilitadora da comunicaçăo, fator de qualidade do trabalho, indicador de cultura, forma de propagar o turismo, e, em alguns casos, pré-requisito para o trabalho. 